\title{
IMPLEMENTASI FRAMEWORK LARAVEL DALAM SISTEM PENDAFTARAN MAHASISISWA BARU POLITEKNIK KOTA MALANG
}

\author{
Dwi Wijonarko1, Fajar Wahyu Setyo Budi ${ }^{2}$ \\ 1,Teknik Informatika, Politeknik Kota Malang, 2,Teknik Informatika, Politkenik Kota Malang \\ Jalan Raya Tlogowaru No 3, Kec Kedungkandang Kota Malang \\ 11.wijonarko@poltekom.ac.id, 2fajaws@poltekom.ac.id
}

\begin{abstract}
The purpose of this research is to create a system that can be used to help the UPT Admissions Unit at the Politeknik Kota malang in recording new prospective students, determining the ceiling to the selection process and announcing the admission of new students at the Politeknik Kota Malang which is still being done manually and separate. This system is built on a web platform so that it can be accessed by users wherever and whenever they are connected to an internet connection. The display system is also able to adapt to mobile devices, so users can also access through an internet browser on their respective mobile devices, because the system display has a "Responsive User Interface" function. The expectation and purpose of establishing a new student registration system at the Politeknik Kota Malang is that the recording and managerial process can be well recorded and prospective applicants can get registration information quickly and accurately.
\end{abstract}

Keywords : laravel, Admission System, Web Application

\begin{abstract}
Abstrak
Tujuan dari penelitian ini adalah untuk menciptakan sistem yang dapat digunakan untuk membantu bagian UPT Penerimaan Mahasiswa Baru di Politeknik Kota Malang dalam melakukan pencatatan calon mahasiswa baru, penentuan pagu hingga proses seleksi dan pengumuman penerimaan mahasiswa baru di Politeknik Kota Malang yang selama ini masih dikerjakan secara manual dan terpisah. Sistem ini dibangun dalam platform web sehingga mampu diakses oleh pengguna dimanapun dan kapanpun asal terhubung dengan koneksi internet. Tampilan sistem ini juga mampu beradaptasi dengan perangkat bergerak,sehingga pengguna juga dapat mengakses melalui peramban internet pada perangkat bergerak masing-masing, karena tampilan sistem sudah memilik fungsi "Responsive User Interface". Harapan dan tujuan dibangunnya sistem pendaftaran mahasiswa baru di Politeknik Kota Malang adalah proses pencatatan dan manajerial dapat ter-record dengan baik dan calon pendaftar bisa mendapatkan informasi pendaftaran secara cepat dan akurat.
\end{abstract}

Kata kunci : Laravel, Penerimaan Mahasiswa Baru, Aplikasi Web

\section{Pendahuluan}

Politeknik Kota malang adalah merupakan salah satu perguruan tinggi swasta yang berada di Kota Malang Jawa Timur. Didirikan tahun
2008, saat ini memiliki 3 (Tiga) program studi yaitu Teknik Informatika (D3), Teknik Telekomunikasi (D3) dan Teknik Mekatronika (D3) [1]. 
Sebagai kampus yang memiliki platform Information technology, maka segala aspek kegiatan yang dilaksanakan diharapkan selalu menggunakan konsep dan pemanfaatan TIK (teknologi informasi dan komunikasi) salah satunya adalah penggunaan komputerisasi di setiap aktivitas kerja termasuk pada saat penerimaan mahasiswa baru.

Tujuan dari penelitian ini adalah untuk menciptakan sistem yang dapat digunakan untuk membantu bagian UPT Penerimaan Mahasiswa Baru di Politeknik Kota Malang dalam melakukan pencatatan calon mahasiswa baru, penentuan pagu hingga proses seleksi dan pengumuman penerimaan mahasiswa baru di Politeknik Kota Malang yang selama ini masih dikerjakan secara manual dan terpisah.

Sistem ini dibangun dalam platform web sehingga mampu diakses oleh pengguna dimanapun dan kapanpun asal terhubung dengan koneksi internet. Tampilan sistem ini juga mampu beradaptasi dengan perangkat bergerak,sehingga pengguna juga dapat mengakses melalui peramban internet pada perangkat bergerak masing-masing, karena tampilan sistem sudah memilik fungsi "Responsive User Interface".

Harapan dan tujuan dibangunnya sistem pendaftaran mahasiswa baru di Politeknik Kota Malang adalah proses pencatatan dan manajerial dapat ter-record dengan baik dan calon pendaftar bisa mendapatkan informasi pendaftaran secara cepat dan akurat.

\section{Tinjauan Pustaka dan Teori}

\section{A. Tinjauan Pustaka}

Implementasi Framework Twitter Bootstrap Dalam Perancangan Aplikasi Penerimaan Mahasiswa Baru Berbasis Web [2] Dalam mendesain template aplikasi berbasis web, programmer web menggunakan sintaks-sintaks CSS untuk membuat tampilan menjadi lebih menarik. Dalam perkembangannya banyak tooltool atau framework CSS yang dapat dimanfaatkan untuk mempercepat pengerjaan desain template web, diantaranya Gumby, Foundation, Less Framework, Blueprint CSS dan Twitter Bootstrap. Dari beberapa framework CSS tersebut, Twitter Bootstrap hadir dengan tutorial dan dokumentasi yang berlimpah serta memiliki fitur responsive. Pada penelitian ini penulis megimplementasikan framework Twitter Bootstrap pada perancangan aplikasi penerimaan mahasiswa baru berbasis web. Tahapan yang diambil dalam perancangan Aplikasi Penerimaan
Mahasiswa Baru ini diawali dengan mendownload Twitter Bootstrap dari website resminya dan melakukan ekstraksi ke folder project setelah itu baru class-class yang disediakan oleh Twitter Bootstrap dapat dipanggil dalam pengerjaan desain aplikasi. Dengan penerapan framework twitter bootstrap ini pengerjaan desain aplikasi lebih cepat karena tidak perlu lagi memikirkan sintaks-sintaks css dan menghasilkan template yang responsive, ringan dan simple.

Implementasi Framework Laravel Pada Aplikasi Pengolah Nilai Akademik Berbasis Web [3] Nilai merupakan salah satu hal penting di sekolah. berdasarkan peraturan menteri pendidikan dan kebudayaan Republik Indonesia nomor 66 tahun 2013 tentang standar penilaian pendidikan menyebutkan bahwa hasil penilaian oleh pendidik dan satuan pendidikan dilaporkan dalam bentuk nilai dan deskripsi pencapaian kompetensi kepada orang tua dan pemerintah. Nilai dan deskripsi pencapaian kompetensi siswa masih diolah secara manual sehingga membutuhkan waktu lama dalam pengerjaannya. Untuk itu dibutuhkan sebuah aplikasi yang dapat mengolah nilai. Pembuatan aplikasi web pengolahan nilai siswa adalah salah satu solusi untuk mengatasi lambatnya pengolahan nilai. Aplikasi web pengolahan nilai ini dibuat menggunakan model waterfall yang mencakup : analisis, desain, pengkodean dan pengujian. pada website ini penilaian diproses berdasarkan standar kurikulum 2013 yang memiliki tiga kompetensi nilai yaitu pengetahuan, keterampilan dan sikap. Hasil akhir dari ketiga nilai tersebut diproses menjadi nilai rapor. Pembuatan web ini menggunakan bahasa pemrograman PHP dan penyimpanan basis data MySQL. Dari hasil penelitian yang dilakukan diperoleh kesimpulan bahwa Aplikasi Web Pengolahan Nilai merupakan solusi yang membantu proses pengolahan nilai bagi wali kelas dan kemudahan bagi siswa untuk melihat nilainya.

Perancangan Sistem Aplikasi Penerimaan Mahasiswa Baru Di Stmik Pringsewu Menggunakan Php Dan Mysql [4] Stmik Pringsewu adalah salah satu instansi pendidikan di Lampung yang merupakan instansi terfavorit yang berada di wilayah kabupaten Pringsewu. Stmik Pringsewu sudah mempunyai website tetapi belum melayani pendaftaran mahasiswa 
baru secara online. Meskipun begitu pada perkembangannya, calon mahasiswa baru yang berminat untuk sekolah atau mendaftar di Stmik Pringsewu tersebut semakin banyak, baik yang dari dalam kota maupun yang dari luar kota, baik yang baru lulus SMU/sederajat maupun yang sudah bekerja. Sehingga dalam perkembangannya tersebut memerlukan pelayanan secara cepat dan tidak membutuhkan waktu yang lama. Dari penelitian yang dilakukan di Stmik Pringsewu, bahwa dengan adanya sistem aplikasi penerimaan mahasiswa baru ini akan mempermudah panitia dalam pengolahan data calon mahasiswa baru dalam proses pendaftaran calon mahasiswa baru sampai proses penerimaan mahasiswa baru yang berada diluar daerah maupun didalam, khususnya wilayah provinsi Lampung, dan menyajikan informasi seputar penerimaan mahasiswa baru bisa diakses langsung melalui media website.

\section{B. Laravel}

Laravel Framework merupakan sebuah kerangka kerja pemrograman yang berbasis open source yang dipakai oleh banyak developer dari seluruh dunia [5]. Menurut Mulyadi, kemudahan penggunaan dan dokumentasi yang lengkap menjadi salah satu faktor mengapa Laravel menjadi primadona dalam beberapa tahun terakhir.

Laravel mengikuti pola arsitektur Model-ViewController (MVC). MVC memisahkan aplikasi berdasarkan komponen-komponen aplikasi, seperti manipulasi data, controller, dan user interface. Keuntungan pengembangan aplikasi ini adalah dalam proses maintenance dan scalability yang lebih mudah.

1) Model. Model mewakili struktur data. Biasanya model berisi fungsi-fungsi yang membantu seseorang dalam pengelolaan basis data seperti memasukkan data ke basis data, pembaruan data dan lain-lain.

2) View. View adalah bagian yang mengatur tampilan ke pengguna. Bisa dikatakan berupa halaman web.

3).Controller. Controller merupakan bagian yang menjembatani model dan view.

\section{Responsive User Interface}

Responsive User Interface merupakan fitur dari halaman web dimana halaman tersebut mampu menyesuaikan tampilan dengan perangkat yang sedang mengaksesnya. Dengan adanya fitur ini, halaman web akan tetap nyaman dan enak dipandang baik ketika dilihat pada perangkat komputer maupun perangkat mobile yang tampilannya lebih kecil.

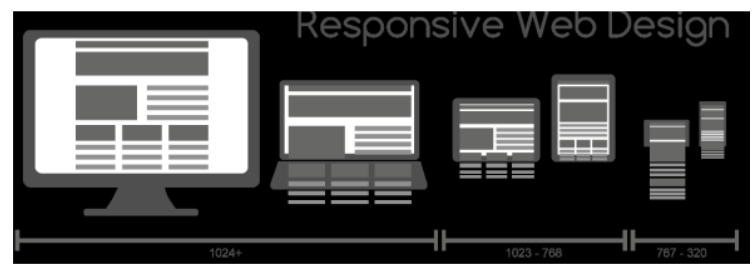

Gambar 1. Ilustrasi Responsive Web Design

Situs web responsif menampilkan konten berdasarkan ruang browser yang tersedia. Apabila halama web dibuka menggunakan peramban komputer yang responsif dan kemudian mengubah ukuran jendela peramban, konten akan optimal untuk jendela browser. Pada ponsel, proses ini otomatis; situs memeriksa ruang yang tersedia dan kemudian menampilkan dirinya dalam pengaturan yang ideal.

Bootstrap Framework, merupakan kerangka kerja untuk tampilan yang memiliki kemampuan untuk membuat halaman web secara responsive. Dengan menggunakan framework ini, peneliti tidak perlu memikirkan perilaku halaman apabila dibuka di berbagai ukuran peramban, karena sudah ditangani oleh framework bootstrap tersebut.

\section{Metodologi Penelitian}

\section{A. Tahapan}

Penelitian ini terrmasuk jenis penelitan R\&D (Research and Development). Penelitian Rancang Bangun Sistem Pendaftaran Mahasiswa Baru Politeknik Kota Malang tahapannya dilihat dalam gambar berikut 


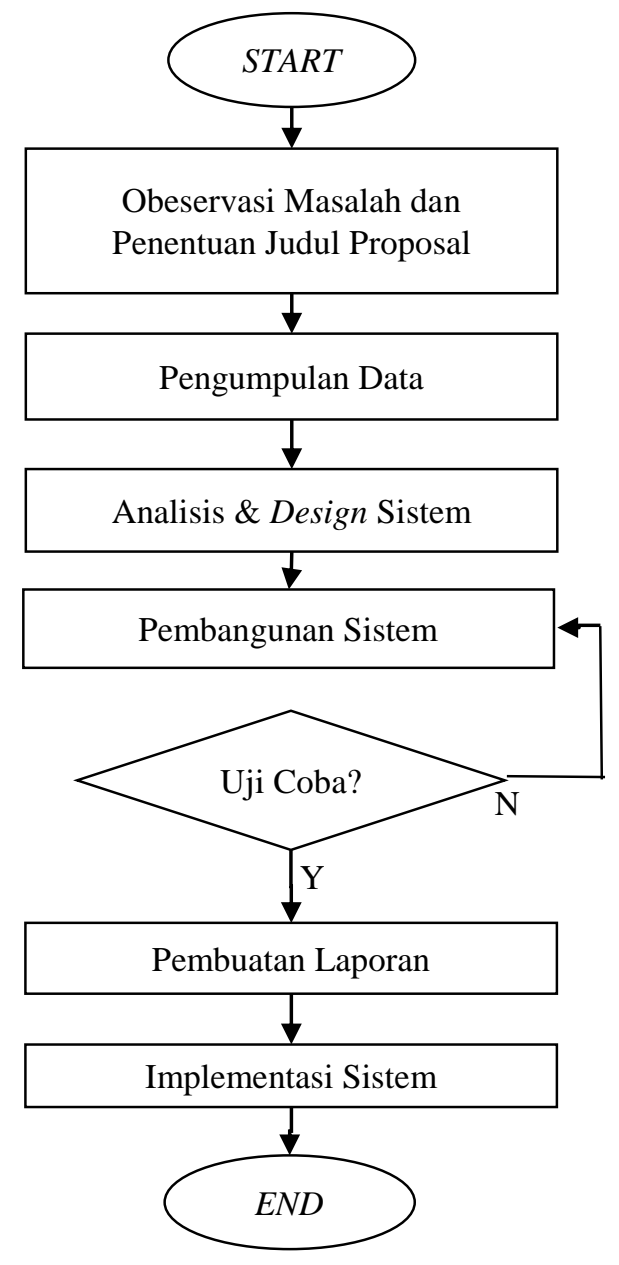

Gambar 2. Tahapan Penelitian

\section{B. Lokasi Penelitian}

Penelitian ini dilaksanakan di Unit Pelaksana Teknis (UPT) Penerimaan Mahasiswa Baru (PMB) Politeknik Kota Malang, Jalan Raya Tlogowaru No3, Kedungkandang Kota Malang.

\section{Struktur Informasi}

Adapun struktur informasi yang dari Sistem Pendaftaran Online Mahasiswa Baru Politeknik Kota Malang

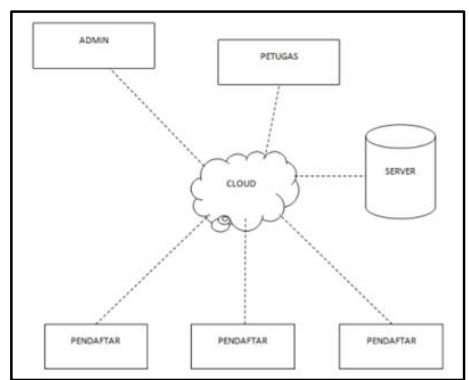

Gambar 3. Struktur Informasi

\section{Proses Bisnis}

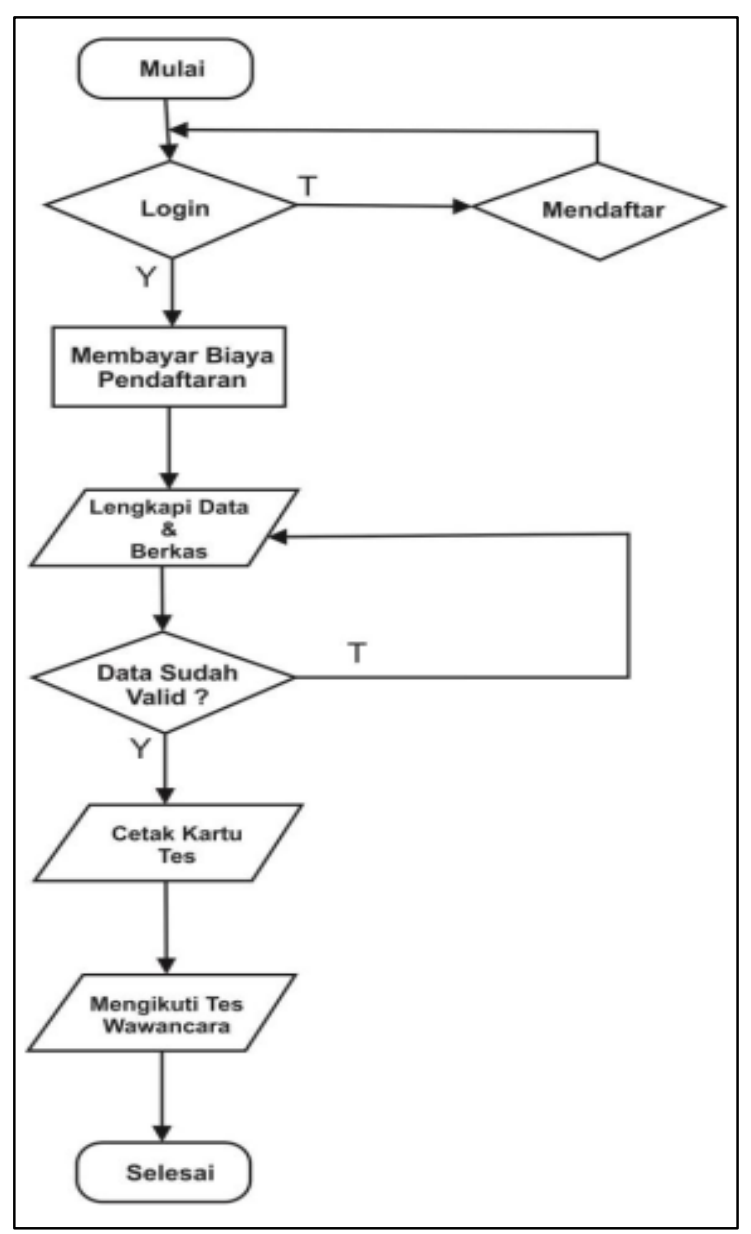

Gambar 4. Proses Bisnis

\section{Hasil dan Pembahasan}

Implementasi merupakan rangkaian kegiatan yang di lakukan setelah perancangan sistem dengan tujuan yang ingin di capai dan dapat di operasikannya rancangan yang telah di buat. Pada tahap ini akan di jelaskan beberapa komponen yang di perlukan dalam pembuatan sistem serta pembatasan dalam pembuatan sistem antara lain sebagai berikut

\section{Kebutuhan Hardware (Perangkat Keras)}

Berikut ini merupakan hardware (perangkat keras) dalam penelitian ini

1. Processor : Intel Core i3

2. Memory : $2 \mathrm{~GB}$

3. Hardisk : $500 \mathrm{~GB}$ 


\section{Kebutuhan Software (Perangkat Lunak)}

Berikut ini adalah software yang digunakan untuk membangun Situs Pendaftaran Online Politeknik Kota Malang :
1. Sistem Operasi Server Windows / Linux

2. PHP 7.121

3. MySQL 6.0.8

Data Flow Diagram

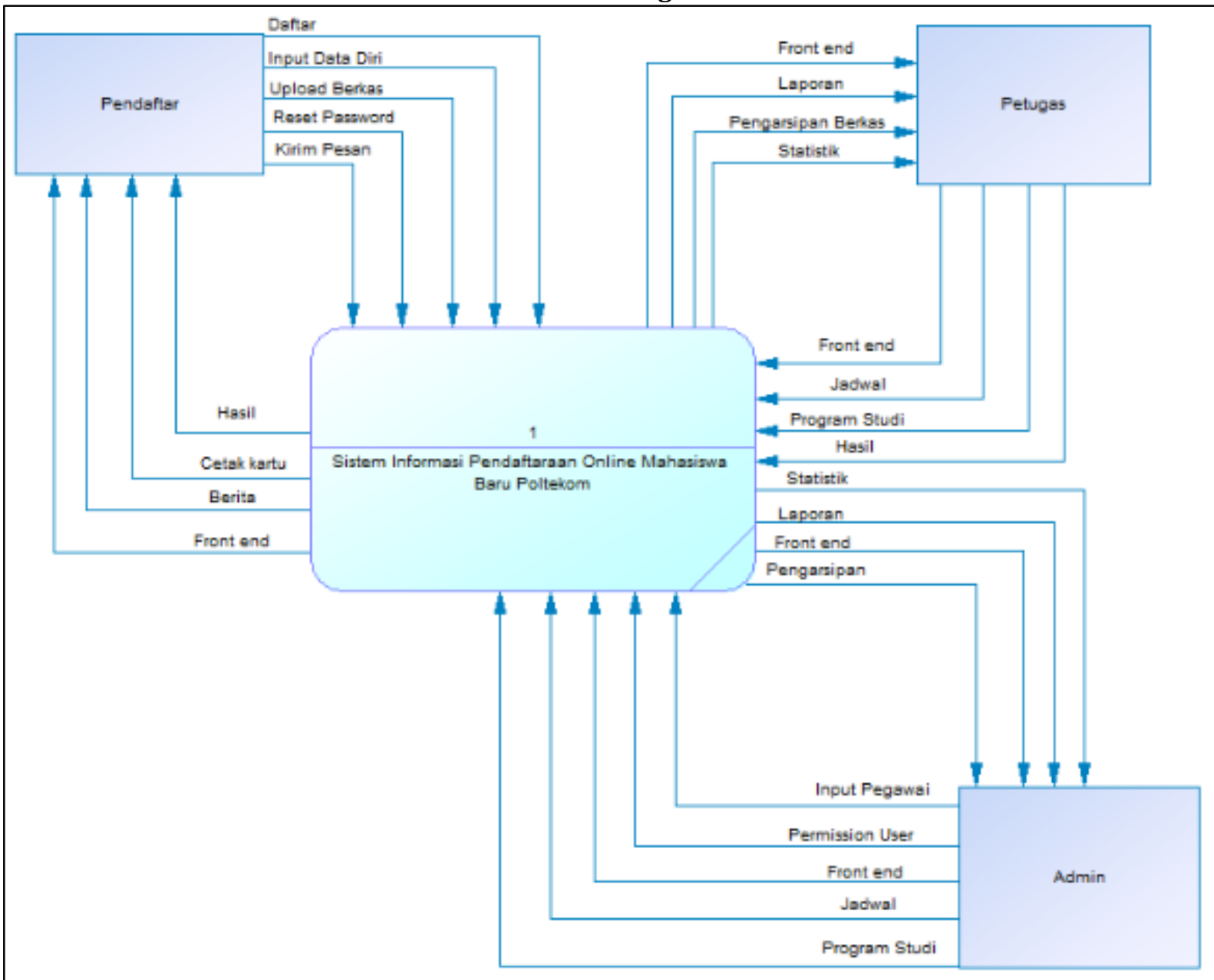

Gambar 5. Diagram Konteks 


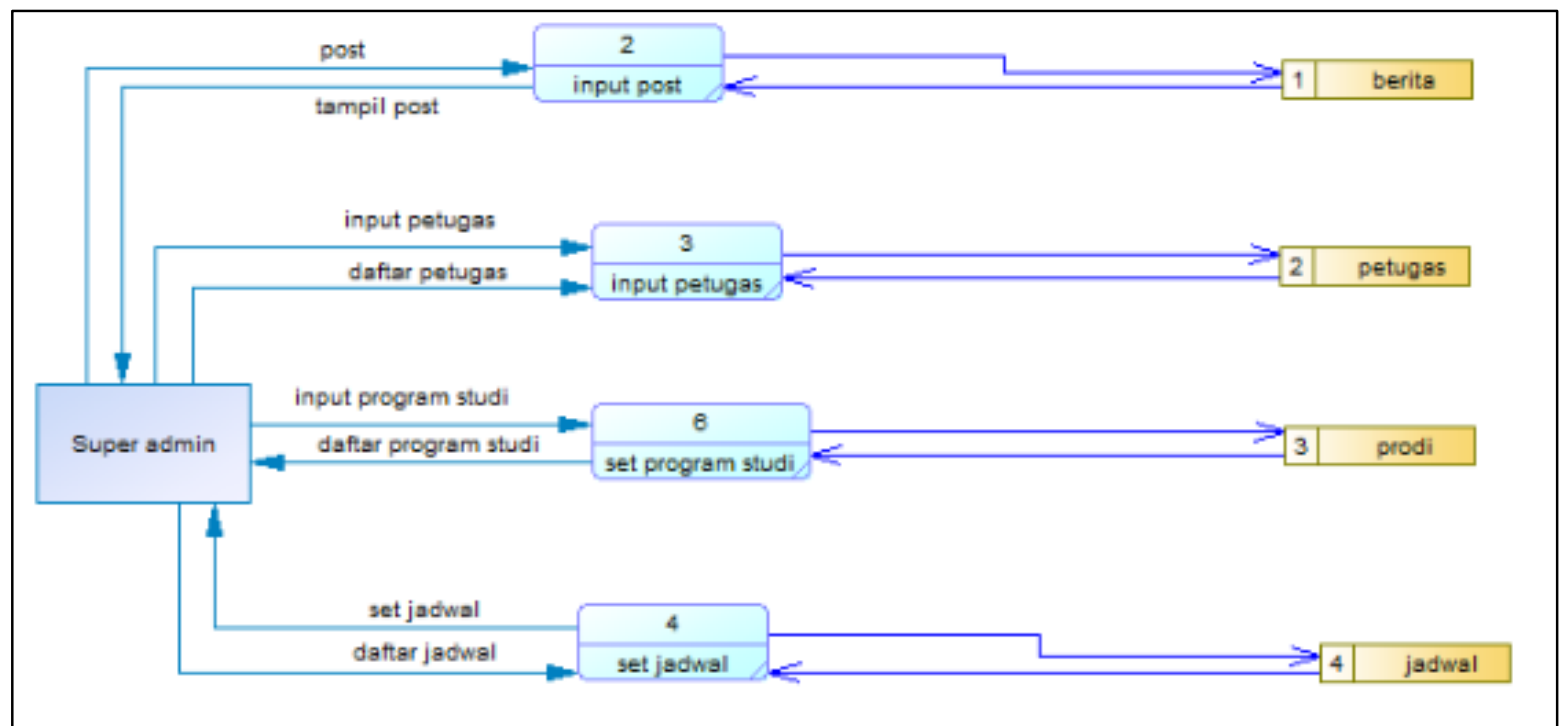

Gambar 6. DFD Level 1 Admin

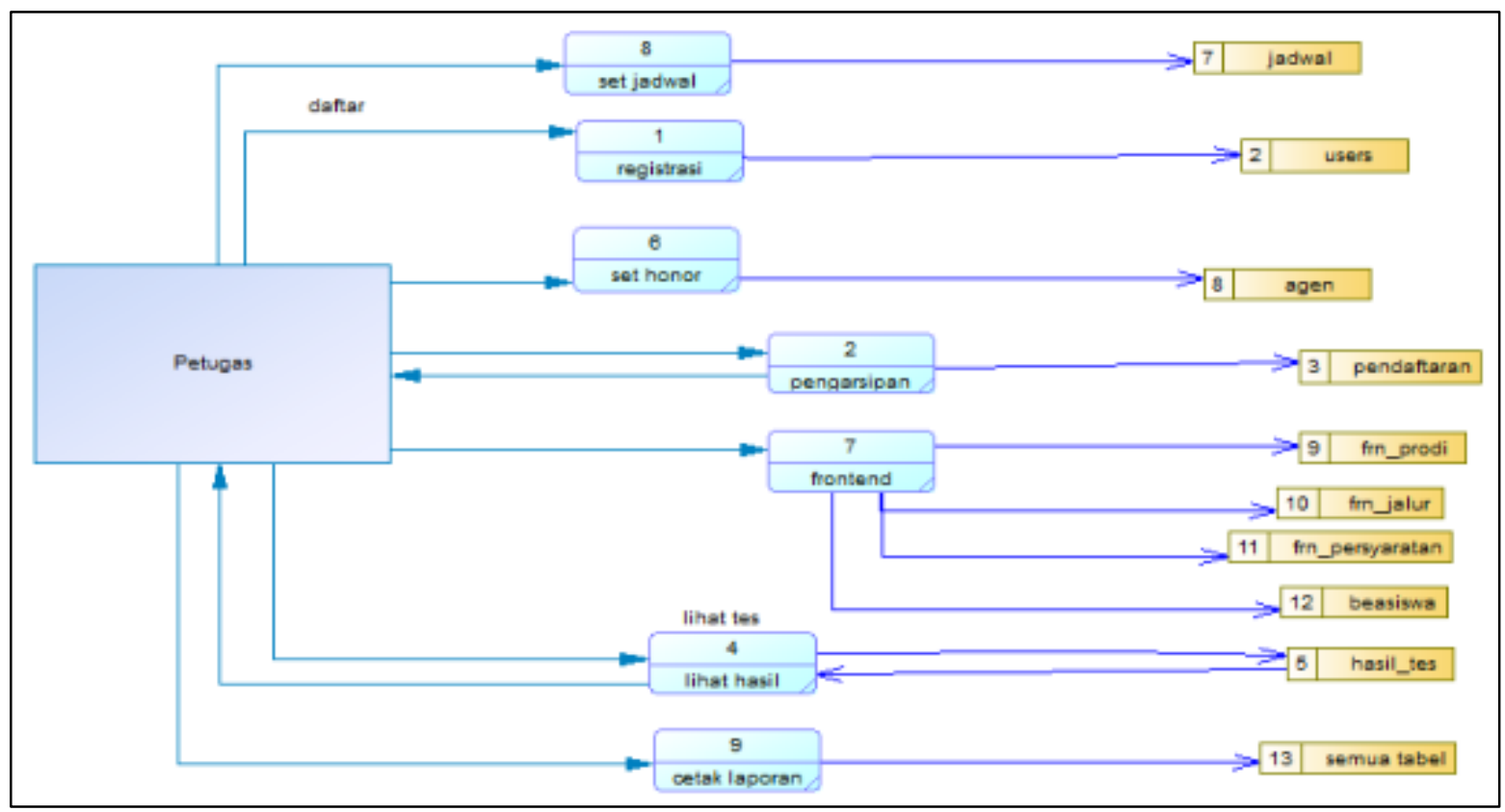

Gambar 7. DFD Level 1 Petugas 


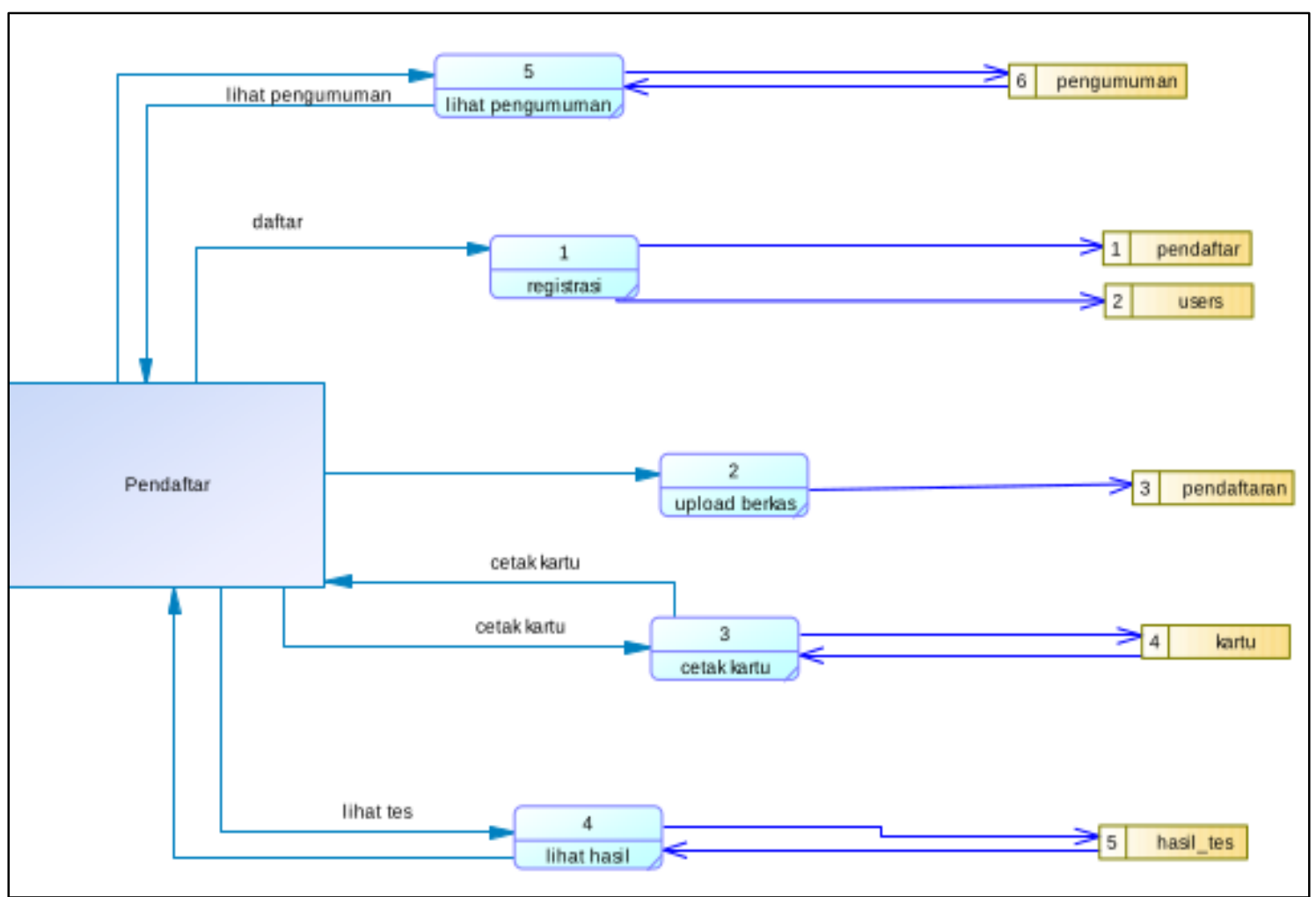

Gambar 8. DFD Level 1 Pendaftar

Hasil Aplikasi (Front End)

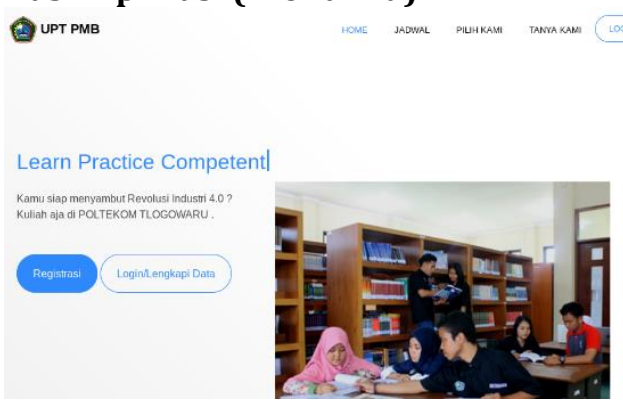

Gambar 9. Front End

\section{Hasil Aplikasi Back End}

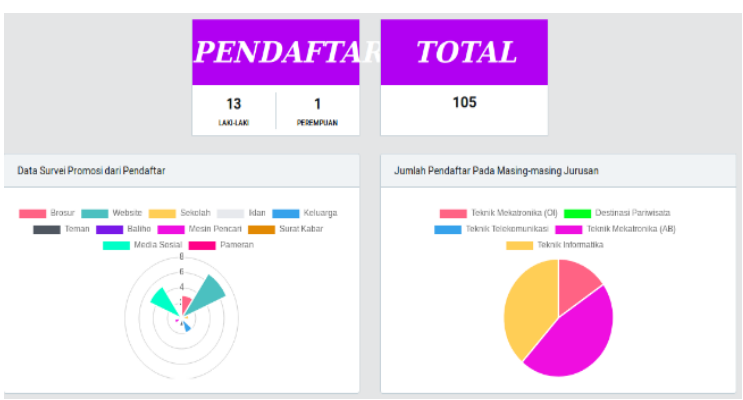

Gambar 10. Hasil Aplikasi Back End

\section{Kesimpulan dan Saran}

Dengan adanya "Sistem Informasi Pendaftaran Online Mahasiswa baru Politeknik Kota Malang" ini, proses pendaftaran yang meliputi pengisian data diri, melengkapi berkas, penentuan jadwal tes dan cetak laporan dapat dilakukan lebih mudah. Berkas-berkas yang diunggah oleh pendaftar dapat diarsip oleh pegawai agar bisa digunakan untuk masa yang akan mendatang sehingga mahasiswa nantinya tidak perlu diminta untuk memberikan berkas-berkas yang telah ditentukan.

Setelah dilakukan pengujian dan evaluasi yang telah dilakukan, maka penulis menyarankan untuk pengembangan penelitian dimasa yang akan datang yaitu "Sistem Informasi Pendaftaran Online Mahasiswa Baru Politeknik Kota Malang dapat dikembangkan dengan menambahkan fitur pendaftaran Politeknik Kota Malang". 


\section{Daftar Pustaka}

[1] Anonymous, "Wikipedia Politeknik Kota Malang," 2019. [Online]. Available:

https://id.wikipedia.org/wiki/Politek nik_Kota_Malang. [Accessed 0111 2019].

[2] M. A. Rosid and R. B. Jakaria, "IMPLEMENTASI FRAMEWORK TWITTER BOOTSTRAP DALAM PERANCANGAN APLIKASI PENERIMAAN MAHASISWA BARU BERBASIS WEB," Kinetik, vol. 1, no. 3, p. 126, 2016.

[3] S. Susanti, E. Junianto and R. Rachman, "Implementasi Framework Laravel Pada Aplikasi Pengolah Nilai Akademik Berbasis Web," Jurnal Informatika, vol. 4, no. 1, 2017.

[4] M. Muslihudin and A. Larasati, "PERANCANGAN SISTEM APLIKASI PENERIMAAN MAHASISWA BARU DI STMIK PRINGSEWU MENGGUNAKAN PHP DAN MYSQL," Jurnal TAM (Technology Acceptance Model), vol. 3, 2014.

[5] Mulyadi, Sistem Akuntansi, Edisi ke-3, Cetakan ke 5, Salemba Empat, 2015.

[6] Lombok, W. B. S. (2016). Analisis Tingkat Kematangan Sistem Informasi Akademik Menggunakan Framework

[7] COBIT 4.1 (Studi Kasus: STMIK Lombok). Speed-Sentra Penelitian Engineering dan Edukasi, 8(1).

Najamudin, N., Bagye, W., \& Ashari, M. (2019). Aplikasi Penerimaan Peserta Didik Baru Berbasis Web Pada Smk Negeri 2 Kuripan. Jurnal Manajemen Informatika dan Sistem Informasi, 2(2), 17-26.

[8] Khairul Imtihan. "Perencanaan Strategi Sistem Informasi Pendidikan Pada Sekolah Tinggi Manajemen Informatika dan Komputer (STMIK) Lombok." Bianglala Informatika 3.2 (2015).

[9] Fadli, S., \& Imtihan, K. (2019). Implementation of MOORA Method in Evaluating Work Performance of Honorary Teachers. SinkrOn, 4(1), 128-135. 